\title{
Shared heritability of attention-deficit/hyperactivity disorder and autism spectrum disorder
}

\author{
Nanda N. J. Rommelse $\cdot$ Barbara Franke • \\ Hilde M. Geurts · Catharina A. Hartman · \\ Jan K. Buitelaar
}

Received: 12 August 2009/Accepted: 8 January 2010/Published online: 11 February 2010

(C) The Author(s) 2010. This article is published with open access at Springerlink.com

\begin{abstract}
Attention-deficit/hyperactivity disorder (ADHD) and autism spectrum disorder (ASD) are both highly heritable neurodevelopmental disorders. Evidence indicates both disorders co-occur with a high frequency, in 20-50\% of children with ADHD meeting criteria for ASD and in 30$80 \%$ of ASD children meeting criteria for ADHD. This review will provide an overview on all available studies [family based, twin, candidate gene, linkage, and genome wide association (GWA) studies] shedding light on the role of shared genetic underpinnings of ADHD and ASD. It is concluded that family and twin studies do provide support
\end{abstract}

N. N. J. Rommelse $(\varangle) \cdot$ B. Franke $\cdot$ J. K. Buitelaar Department of Psychiatry, Donders Institute for Brain, Cognition and Behavior, Radboud University Nijmegen Medical Center, Reinier Postlaan 10, 6525 GC Nijmegen, The Netherlands

e-mail: n.lambregts-rommelse@psy.umcn.nl;

j.buitelaar@psy.umcn.nl

N. N. J. Rommelse · J. K. Buitelaar

Karakter Child and Adolescent Psychiatry University Center

Nijmegen, Nijmegen, The Netherlands

B. Franke

Department of Human Genetics, Radboud University Nijmegen

Medical Center, Nijmegen, The Netherlands

H. M. Geurts

Department of Psychonomics, University of Amsterdam, Amsterdam, The Netherlands

H. M. Geurts

Dr Leo Kannerhuis, Amsterdam Clinic, Amsterdam,

The Netherlands

\section{A. Hartman}

Department of Psychiatry, University Medical Center

Groningen, University of Groningen, Groningen,

The Netherlands for the hypothesis that ADHD and ASD originate from partly similar familial/genetic factors. Only a few candidate gene studies, linkage studies and GWA studies have specifically addressed this co-occurrence, pinpointing to some promising pleiotropic genes, loci and single nucleotide polymorphisms (SNPs), but the research field is in urgent need for better designed and powered studies to tackle this complex issue. We propose that future studies examining shared familial etiological factors for ADHD and ASD use a family-based design in which the same phenotypic (ADHD and ASD), candidate endophenotypic, and environmental measurements are obtained from all family members. Multivariate multi-level models are probably best suited for the statistical analysis.

Keywords Attention-deficit/hyperactivity disorder . Autism spectrum disorder - Molecular genetics .

Shared heritability

\section{Introduction}

Based on their diagnostic descriptions, attention-deficit/ hyperactivity disorder (ADHD) and Autism Spectrum Disorder (ASD) have little in common. ADHD is characterized by severe inattention, hyperactivity, and impulsivity, whereas ASD is characterized by impaired communication and social interaction skills, as well as repetitive and restricted behavior and interests [3]. However, in clinical practice it is commonly observed that a child with ADHD shows symptoms of ASD and vice versa. Moreover, ADHD and ASD appear to co-occur in families, with one child for instance having ADHD and the other child having ASD or a combination of both disorders. Despite these clinical observations, the diagnostic 
guidelines in the Diagnostic and Statistical Manual of Mental Disorders 4th edition (DSM-IV) [3] prevent making a comorbid diagnosis, based on the rationale that ADHDlike symptoms in patients with ASD are primarily attributable to the ASD diagnosis. This argument is widely disputed, and it is now commonly believed that both disorders can co-occur.

Several studies have made an estimation of the cooccurrence rates of $\mathrm{ADHD}$ and $\mathrm{ASD}$, by examining the prevalence of ASD in ADHD samples and vice versa. Estimations vary substantially; based on the lowest and highest reported prevalence rates, $20-50 \%$ of children with ADHD meet criteria for ASD and 30-80\% of ASD children meet criteria for ADHD [20, 32, 43, 47, 51, 81, 86, 88, 100]. Much less is known about co-occurrence rates in adults. Two studies indicate that $40-50 \%$ of patients with autistic disorder or atypical autism, 28-36\% of patients with Asperger syndrome and around 52\% of patients with PDD-NOS, fulfill the criteria for ADHD (including ADHD in remission) [4, 46]. The interpretation of comorbidity rates from clinical samples, however, is limited due to possible referral bias. A further complicating factor in all of these studies, is the entanglement of symptom descriptions of both disorders. That is, inattention (a core symptom of ADHD) can easily be mistaken for social inattention (a core symptom of ASD), resulting in inflated co-occurrence rates of both disorders. Ideally, prevalence rates of ADHD in ASD are calculated both in a loose manner and a stringent manner, in which the latter refers to correcting for the population prevalence of ADHD when calculating prevalence rates of ADHD in an ASD sample and vice versa. Or, even better, a factor analysis on a pool of ADHD and ASD items should be performed, excluding the items that show too much cross-correlation, in order to extract more pure constructs of ADHD and ASD. Such a stringent approach to study the co-occurrence of ADHD and ASD, however, has yet to be performed. Nevertheless, despite the shortcomings of the studies reporting on co-occurrence rates of $\mathrm{ADHD}$ and $\mathrm{ASD}$, it is undeniable that both disorders can co-occur in the same patient.

However, due to the DSM-IV diagnostic restrictions, little is known about the nature of the co-occurrence of ADHD and ASD. The co-occurrence of two disorders may be caused by a variety of reasons. First, as mentioned above, it may be related to overlapping diagnostic criteria, resulting in inflated co-occurrence rates. As far as the authors know, no studies exist that have performed a factor analysis on ADHD and ASD DSM-IV derived items to examine the extent of overlapping diagnostic criteria. Even though it is of vital concern to examine the interrelatedness of both construct descriptions, we do not believe the co-occurrence of ADHD and ASD can be completely explained by overlapping diagnostic criteria. Second, co-occurrence of ADHD and ASD may be caused by one disorder leading to the other. In this scenario, treatment of one disorder might improve symptoms of the other disorder as well. This appears not to be the case: Psychostimulants and noradrenergic reuptake inhibitors appear effective in the treatment of ADHD symptoms in patients with a combined diagnosis of ADHD + ASD, but do not have a substantial effect on the ASD symptoms [2, 41, 70, 83, 95]. Also the age of onset and developmental sequence of ASD and ADHD do not support a likely model of one disorder leading to the other. For ASD has by definition an earlier onset than ADHD, and would then be causing ADHD. However, in most if not all ASD plus ADHD cases the first clinical presentation includes the simultaneous expression of ASD and ADHD symptoms. Another theoretical possibility is that one of the disorders produces a phenocopy of the other. A phenocopy is an individual whose phenotype, under a particular environmental condition, is identical to the one of another individual whose phenotype is determined by the genotype. In other words, the phenocopy environmental condition mimics the phenotype produced by a gene. An example of a phenocopy in the context of this paper would be a child with a strong genetic predisposition for ADHD but growing up in a rigid, bizar, and unempathic family. This could lead to the expression of the ADHD phenotype, on the basis of the genotype, in addition to the expression of an ASD phenotype, on the basis of the specific environmental condition. This does not seem to be a likely model, however. Two final explanations for the co-occurrence of ADHD and ASD may be that they are separable and independent disorders occurring together-for example by their association with a third independent factor-or alternatively, they share a common underlying etiology $[6,10,15,19,36]$. We believe that the latter is true and the most likely model, and that both disorders partly shared a common genetic basis. This will be the main topic of the current review.

Both ADHD and ASD are disorders with a strong heritable component. In ADHD, approximately $76 \%$ of the phenotypic variance is explained by heritable factors [29]; in ASD, heritability has been estimated as $>90 \%$ for the narrow sense phenotype of classic autism [33], but may be lower for the broad sense phenotype (although the broad sense phenotype is more prevalent amongst first- and second-degree relatives of ASD probands [69]). For both disorders, oligogenic and multifactorial modes of inheritance have been proposed, but relatively little progress has yet been made in identifying the genes involved [31, 33]. This may be (partly) due to clinical and genetic heterogeneity [55] as well as to other factors [18]. How then should we proceed in our search for common genetic risk factors for ADHD and ASD? We will try to answer this question by systematically reviewing the literature for studies that have examined ADHD and ASD in a family-based design 
or in a twin design. The former will provide insight into the familiality (caused by both heritable factors as well as shared environmental factors) of ADHD + ASD. The latter more directly examines the extent of common genetic factors underlying ADHD + ASD, but has the disadvantage that findings are most often based on community samples instead of clinical samples. The disadvantage of community twin samples is that they have a very low rate of clinical disorders such as ASD. Community twin samples are very useful for the study of subclinical traits across the continuum but much less for clinical disorders as ASD. In addition, we provide an overview of possible overlapping candidate genes and genome-wide association findings for both disorders. A summary is provided with candidate endophenotypic measures (heritable, vulnerability traits) that may be useful for unraveling the shared etiological underpinnings of ADHD and ASD. Finally, we propose several steps for future molecular genetic studies. By providing a comprehensive overview of the currently available findings with respect to shared genetic underpinnings of ADHD and ASD, the current review aims to make an important contribution to the research field and facilitate future genetic studies for ADHD + ASD.

\section{Familial aggregation}

Only two related studies originating from the IMAGE cohort (International Multicenter ADHD Genetic study) [7] have examined the rates/severity of ASD in probands with ADHD and their siblings [61, 64]. Importantly, in both studies, probands and siblings with full autistic disorder were excluded from participation. As far as we know, no studies exist reporting on ADHD in family members of ASD probands. In the Mulligan et al. study [61], autism symptoms were measured using the Social Communication Questionnaire (SCQ) and compared in 821 ADHD probands, 1,050 siblings and 149 controls. As expected, probands (males and females) had higher SCQ scores than siblings and controls. In turn, affected and unaffected male siblings, but not female siblings, had higher SCQ scores than controls. The phenotypic correlation between ADHD and ASD was also slightly higher for males (0.63) than females (0.49). The sibling cross-correlation, indicative of shared familial influences on ADHD and ASD was 0.18 for males, of which $56 \%$ can be attributed to shared genetic influences on ADHD and ASD. This percentage has been calculated by a modified method of the deFries-Fulker analysis. In this analysis, a comparison is made of the mean symptom scores of the proband and the sibling with the mean population scores. See Mulligan et al. [61] for details. These findings suggest that, at least in males, ASD symptoms are familial within ADHD families which likely represent genetic rather than shared environmental factors. While results did not support this hypothesis in females, it must be noted that due to the large predominance of male patients in the sample (88\%), cross-correlation could not be robustly estimated and firm conclusions regarding the shared familiality of ADHD and ASD symptoms in females cannot be drawn.

In the Nijmeijer et al. study [64], a similar approach was taken on the Dutch subsample of the IMAGE dataset. ASD symptoms were measured using the Children's Social Behavior Questionnaire (CSBQ) in 256 sibling pairs and 147 controls. Some important differences exist between the CSBQ used in the Nijmeijer et al. study and the SCQ used in the Mulligan et al. study. The 49-item CSBQ is an instrument able to measure less severe variants of ASD symptomatology and ASD related problems (such as problems in executive functioning and disruptive behavior), whereas the SCQ is designed to measure the more severe ASD characteristics. Furthermore, the CSBQ uses a 3-point Likertscale, in contrast to the 'yes' and 'no' response options used in the SCQ. Similarly, the study of Mulligan et al. indicated that both probands and siblings had higher ASD scores than controls, ADHD and ASD correlated phenotypically (0.40) and sibling correlations for ASD were significant. Contrary to the results of the Mulligan study was the finding that the sibling correlations for ASD were higher in female probands (0.44) than male probands (0.23), suggesting ASD to be more highly familial in females with ADHD compared to males with ADHD. In addition, sibling correlations for ASD were generally higher in older than younger children, possibly indicating an increased genetic influence on ASD within ADHD families over time. Last, sibling cross-correlations between ADHD and ASD were non-significant, suggesting that independent familial factors give rise to ADHD and ASD. This latter finding contrasts somewhat with the significant albeit small $(r=0.18)$ sibling crosscorrelations for ADHD and ASD reported by Mulligan et al. yet may be explained by the substantially smaller sample size and use of a qualitatively different questionnaire in the Nijmeijer et al. study. However, it is safe to say that ASD symptoms are familial within ADHD families, as indicated by elevated ASD symptom levels in affected and nonaffected siblings of ADHD probands and significant sibling correlations. Whether ADHD and ASD symptoms arise from shared familial (and genetic) origins within clinically ADHD affected children, and whether this is influenced by age and gender, remains to be investigated.

\section{Twin studies}

Constantino et al. [23] were the first to report shared additive genetic influences on symptoms of ASD (measured with the Social Reciprocity Scale) and attention 
problems (measured with the Child Behavior Checklist) in 219 pairs of male twins aged 7-15 years. Two recent twin studies examined more directly the genetic correlations between ADHD and ASD symptoms [75, 79]. One study examined parent and teacher reported symptoms of ADHD (using the Conners') and ASD (using the Childhood Asperger Syndrome Test) in a large $(N=6,771)$ sample of 8 year old twins [79]. Phenotypic correlations between ADHD and ASD were 0.54 for parent and 0.51 for teacher data. Genetic correlations between ASD and ADHD symptoms were all $>0.50$, suggesting a moderate degree of overlap between ASD and ADHD, both throughout the general population and at the quantitative extreme. A model incorporating additive genetic influences and unique environmental influences fitted the data best. Findings were robust for influences of rater, sex, IQ, and comorbid conduct problems.

Quite similar results were reported in a study using self reported measures of ADHD (12 DSM-IV items) and ASD (Social Responsiveness Scale) in young adult twins $(N=674)$ [75]. A bivariate model indicated that the genetic correlation between ADHD and ASD was 0.72, suggesting that a substantial proportion of the genetic influences on self-reported ADHD and ASD symptoms may be shared between the two disorders. Again, models with additive genetic effects and unique environmental effects fitted the data best, with no evidence for sex differences.

\section{Molecular genetic studies}

\section{Candidate genes}

Abnormal functioning of catecholaminergic and serotonergic neurotransmission has been reported in both ADHD and ASD [14, 66, 72]. The main focus in ADHD literature has been on dopamine related genes, given that alterations in dopamine neurotransmission is a core feature of ADHD [94]. The main focus in ASD literature has been on serotonin related genes, given that abnormalities in serotonin neurotransmission are robustly reported in ASD [48]. Accordingly, genes related to these pathways have been the prime candidates for molecular investigation in both disorders [5, 87; see also elsewhere in this issue].

\section{Dopamine}

The dopamine transporter gene (DAT1), coding for a sodium-dependent dopamine transporter that mediates reuptake of dopamine at the synapse, is associated with ADHD (see for meta-analysis [37]). The most frequently studied polymorphism is a 40 base pair (bp) variable number of tandem repeat (VNTR) in the $3^{\prime}$-untranslated region. The 9- and 10-repeat alleles are the two most common variants in Caucasians. The 10-repeat is associated with an increased activity of the transporter, resulting in less dopamine in the synaptic cleft. A recent study investigated the association between DAT1 and ADHD symptomatology in 67 children with ASD [34]. In contrast to expectations, the $10 / 10$ homozygous ASD children were rated by mothers as being less inattentive and hyperactiveimpulsive than the 9-repeat carriers. However, given that findings of the 9- versus 10-repeat allele are also mixed in ADHD literature (Franke et al. submitted), with the latter sometimes being the risk variant, other times the protective variant [37], further studies are needed to clarify the role that DAT1 may play in relation to $\mathrm{ADHD}+\mathrm{ASD}$ symptomatology.

Another extensively studied candidate gene for ADHD is the dopamine D4 receptor gene (DRD4). A specific variant of the DRD4 gene associated with ADHD, as indicated by meta-analyses $[37,52]$, is the functional $48 \mathrm{bp}$ VNTR in exon 3. The 7-repeat allele of this VNTR, identified as the risk allele for ADHD, produces fewer or less efficient D4 receptors resulting in less responsiveness to dopamine stimulation. However, when studied in relation to ASD, no association was found between this 7repeat and autism in 136 autism probands recruited from the same geographic regions as a previous ADHD study conducted by the same authors [40], suggesting DRD4 may not be related to ASD.

The dopamine D3 receptor (DRD3) and the DRD4 have been classified as D2-like receptors based on their sequence homologies and similarity of pharmacological and biochemical properties [76]. A possible association between ADHD and DRD3 has been reported [41, 76], although a recent meta-analysis does not indicate $D R D 3$ to be significantly associated with ADHD [37]. Recently, 132 candidate genes were tested for their association with ADHD and ASD in a two stage approach [50]. First, single nucleotide polymorphisms (SNPs) were tested in 144 ASD patients, 110 ADHD patients, and 404 controls. SNPs reaching a significant threshold for association $(p<0.01)$ were tested in a second independent sample of 128 ASD patients, 150 ADHD patients, and two samples of controls ( $N=124$ and 149). Results indicated that in the first and second ASD samples and in a joint statistical analysis, a significant association with SNP rs167771 located in the $D R D 3$ gene was found. The DRD3 gene appeared to be related to stereotyped behavior, liability to side effects of antipsychotic medication, and movement disorders and may therefore have important clinical implications for ASD. Disappointingly, no shared association was found between ADHD and ASD. However, these results should be seen in light of virtually no significant SNP findings for 
both disorders. As the authors noted themselves, they used a strict (possibly overly conservative) Bonferroni correction, making it possible that they missed out on loci that were associated with ADHD and/or ASD.

\section{Serotonin}

ASD is related to serotonergic genes [87]. The human serotonin transporter is encoded by the SLC6A4, SERT, 5$H T T$ genes. The transcriptional activity of this gene is modulated by a repetitive element of differing length in the promoter. A short version leads to a limited transcription and a reduced amount of the transporter. Studies on this polymorphism in relation to ADHD and ASD have been reviewed [87]. The authors concluded that although there is some evidence supporting the association of the polymorphism with both ADHD and ASD, a uniform picture does not emerge and overlap in findings may be best described by dimensional classification of the two disorders. The advantage of the dimensional approach is that one takes full account of all information available. For example, individuals with moderately high but just subthreshold scores are lumped together with subjects with low scores in a categorical approach. In a dimensional approach, the quantitative difference between subthreshold and low scores is taken into account. The authors suggest that studies examining this polymorphism simultaneously in children with ADHD, ASD, and ADHD + ASD may be needed.

\section{Other}

Breakdown of the catecholamines dopamine, adrenaline, and noradrenaline is mediated by the enzyme Catechol-Omethyltransferase (COMT). Multiple studies have investigated the association between ADHD and a functional SNP, Val158Met (rs4680), associated with decreased enzyme activity (Met-allele) and leading to increased intrasynaptic amount of dopamine in the mesocortical dopamine pathway. Mixed results have been found (see for review elsewhere in this issue). A recent study reported that this functional SNP was also related to social phobia in subjects with ASD [35]. However, no relationship was found with ADHD measures within the sample, yet given the small sample size $(N=67)$ no firm conclusions can be drawn on the validity of the COMT gene as a pleiotropic ADHD/ASD gene.

The X-chromosomal gene Monoamine Oxidase A $(M A O A)$ gene codes for a mitochondrial enzyme involved in the pre-synaptic degradation of the monoamines serotonin, norepinephrine, and dopamine [24]. The gene is a candidate for ADHD because it influences those monoaminergic systems that are also etiologically related to
ADHD [25] and MAOA activity can be inhibited by methylphenidate, which also reduces ADHD symptoms. Several studies have indeed found various polymorphisms in MAOA (like a $30 \mathrm{bp}$ repeat in the promoter region, a GA repeat in intron 2 , and a $\mathrm{G} / \mathrm{T}$ in exon 8 ) to be associated with ADHD, with small odds ratio's around 1.31 and 1.94 $[17,25,26,40,55$; see also elsewhere in this issue). A recent study employing a small sample size $(N=43)$ of boys with ASD reported an association between the $30 \mathrm{bp}$ VNTR in the promoter region of the MAOA gene and severity of ADHD in these boys [80]. As the authors indicate, these results suggest that behavioral disturbances in children with and without ASD may share similar pathogenic mechanisms.

Rare mutations

In some cases, a combined diagnosis of ASD and ADHD may be attributable to a premutation in the $5^{\prime}$ untranslated region of the FMRl gene on the X-chromosome. A full mutation in this region ( $>200$ repeats of a CGG trinucleotide) results in Fragile $\mathrm{X}$ syndrome, the most common heritable form of mental retardation [30]. Most individuals with fewer repeats (a premutation: 55-200 repeats) suffer from mild variants of cognitive and behavioral problems seen in individuals with the full mutation. The prevalence of the premutation in the general population (1:813 males and 1:259 females) is much higher than the prevalence of the full mutation alleles [30], thereby making this premutation more relevant for clinical healthcare. Farzin et al. [30] showed that in a relatively small sample $(N=43)$ of boys ( 27 premutation carriers and 16 non-carrier siblings), the premutation was significantly associated with both clinical diagnosis of ASD as well as ADHD symptoms. Thus, in some cases, a combined diagnosis may be linked to premutations in the FMRl gene on the X-chromosome.

In other rare cases, segmental duplications at breakpoints (BP4-BP5) of chromosome 15q13.2-q13.3 may be the underlying cause of ADHD + ASD [59]. The proximal portion of chromosome $15 \mathrm{q}$ is a well-known region of genomic instability that contains many segmental duplications. Deletions at 15q11-q13 on the known breakpoint BP1, BP2, and BP3 can result in Prader-Willi syndrome and Angelman syndrome [59]. A recent study reported on the clinical features of five patients with a BP4-BP5 deletion, three with a BP4-BP5 duplication, and two with an overlapping but smaller duplication extracted from a DNA database of 1,445 unrelated patients submitted consecutively for clinical array comparative genomic hybridisation (CGH) testing at Children's Hospital, Boston and of 1,441 individuals with autism from 751 families in the Autism Genetic Resource Exchange (AGRE) repository. Results indicated that the phenotype of microdeletions or 
duplications at breakpoints BP4 and BP5 were related to ASD, ADHD, minor dysmorphic features, expressive language deficits and cognitive impairment [59].

A deletion of $22 \mathrm{q} 11$ (containing the COMT gene) may also be underlying ADHD + ASD in some rare cases. In 100 cases with this deletion, the known cause of velocardiofacial (VCF) or DiGeorge syndrome, $44 \%$ were diagnosed with at least one of both disorders [65]. Nine percent of cases had a combined diagnosis. In addition, mental retardation was also common.

The rare XXYY syndrome (prevalence 1:18,00040,000) may account for a few ADHD + ASD cases as well. In 95 males with this syndrome, over $72 \%$ had ADHD and over $28 \%$ had ASD [92]. However, given that this syndrome is accompanied by characteristic physical and facial abnormalities (such as tall stature, hypogonadism, dental problems, seizures, infertility) and almost half of the patients show clear white matter abnormalities and enlarged ventricles [92], this syndrome is unlikely to account for many ADHD + ASD cases without clear medical cause. In fact, this conclusion holds for most of the aforementioned rare mutations.

Recently, a plethora of new information on rare mutations (copy number variations, CNVs) and their possible role in ASD has been generated by the genome-wide copy number analyses [17, 22, 38, 57, 85, 102; see also the Autism Chromosome Rearrangement Database (http:// projects.tcag.ca/autism/)]. These studies suggest that a considerable number of ASD cases may be explained by rare genetic variants of intermediate to large effect size. One recent study also reports on genome-wide CNV analysis in ADHD [28]. These findings also help to clarify the joint etiology of ADHD and ASD, which remains to be investigated. Interestingly, though, in the study by Elia et al. [28] CNVs segregating with ADHD were found to be enriched for ASD candidate genes, while in several of the ASD CNV studies, family members of the ASD patients also carrying the CNV had diagnoses of ADHD [57, 98].

Possible overlapping linkage findings

Linkage studies have been performed to identify new chromosomal loci harboring risk genes for ADHD and ASD. With the exception of one study, only an indirect comparison of candidate linkage loci for ADHD and ASD can be made, since all loci are based on studies including patients with either ADHD or ASD. In the latter case, probably ADHD + ASD cases were included, but this was not systematically registered or measured. The linkage study by Bakker et al. [9] analyzed both a narrow phenotype, in which only sib pairs with ADHD were included ( $N=117)$, and a broad phenotype, containing additional sib pairs $(N=47)$, in which one child had an spectrum disorder but also met the full ADHD criteria. For this broad phenotype, suggestive linkage was observed on chromosome $15 q 15$. An overview of the ADHD- or ASD-specific literature provides limited supporting evidence for overlap. When applying a threshold of 2.2 for the multipoint logarithm of odds score (MLS), indicative of suggestive linkage, the ASD regions for suggestive linkage (2q31, 3q26, $7 \mathrm{q} 22,7 \mathrm{q} 36,11 \mathrm{p} 12-13$, and $17 \mathrm{q} 11)$ and those for ADHD (5q13, 5q33, 6q12, 6q22-23, 7p13, 7q21, 9q22, 9q33, $11 \mathrm{q} 22,14 \mathrm{q} 12,15 \mathrm{q} 15.1,16 \mathrm{p} 13,16 \mathrm{q} 23,16 \mathrm{q} 24$, and 17p11) show no overlap between ASD and ADHD [47]. If even looser criteria are applied, linkage peaks for ADHD at $2 q 24,9 q 33,5 p 13,15 q, 16 p 1,16 p 13$, and $17 p 11$ are in the autistic-proximity of peaks previously detected in genome scans for autism [44, 87]. If confirmed, such regions may harbor pleiotropic genes for ADHD and ASD. The 16p13 peak was observed by Smalley et al. [89] in an ADHD affected-sib-pair analysis in 203 families. They found a significant linkage signal (maximum LOD 4.2) on a 12-cM region on chromosome $16 \mathrm{p} 13$, a region already highlighted in three genome scans for ASD. As yet, this linkage signal and those on 5p13 [8, 49, 53, 67, 99] and 9q33 [8, 77, 84] may appear to be the most fruitful loci to search for pleiotropic genes, since both of these loci are supported by at least two independent studies of autism (although not necessarily genome wide significant), and at least one study of ADHD. However, linkage studies of ADHD + ASD samples are warranted before firm conclusions can be drawn.

\section{Genome-wide association studies (GWAS)}

Molecular genetic studies are increasingly using genomewide association study (GWAS) designs. This new analytic approach combines the power to detect genetic variants of small effect size with the possibility to perform hypothesisfree analyses of the entire genome [31]. In GWAS, 100,000 to over 1,000,000 single nucleotide polymorphisms (SNPs) are genotyped across the genome and tested for their association with the disorder. Given that GWA studies are still in their very early beginning, it may be somewhat premature to look for overlapping findings for ADHD and ASD. Nevertheless, Franke et al. [31] recently reviewed the GWAS literature for SNPs associated with ADHD and several of the top-findings from the reviewed studies turned out to be located near to linkage findings in ASD. A summary of these findings for 16 SNPs possibly involved in ASD is given in Table 1. Similarly, we reviewed the literature for SNPs from SNP-based GWAS in ASD [54, 96; genome-wide ASD CNV studies were already mentioned above]. We report in Table 2 ASD GWAS findings that may also be involved in ADHD. Twenty-five SNPs related to $\mathrm{ASD}$, may also be of interest to ADHD. As 
Table 1 Overview of single nucleotide polymorphisms (SNPs) among the top-findings of GWAS in ADHD possibly also involved in ASD (based on Franke et al. [31])

\begin{tabular}{|c|c|c|c|c|c|}
\hline SNP & $\mathrm{Chr}$ & $\begin{array}{l}\text { Position } \\
\text { (bp) }\end{array}$ & Position & Gene function $^{\mathrm{a}}$ & Previous findings for $\mathrm{ASD}^{\mathrm{a}}$ \\
\hline rs272000 & 2 & 116372265 & $\begin{array}{l}\text { Within } 50 \mathrm{~kb} \\
\text { downstream } \\
\text { of DPP10 }\end{array}$ & $\begin{array}{l}\text { Encodes dipeptyl peptidase } 10 \text {, which does not } \\
\text { possess dipeptidyl peptidase activity, but } \\
\text { binds to specific voltage-gated potassium } \\
\text { channels and alters their expression and } \\
\text { biophysical properties. The expression of the } \\
\text { gene is highest in the brain. }\end{array}$ & $\begin{array}{l}\text { The gene contains CNVs potentially } \\
\text { linked to autism [57]. }\end{array}$ \\
\hline rs 10049246 & 3 & 187169435 & $\begin{array}{l}\text { Intron of } \\
A K 309325\end{array}$ & Hypothetical gene of unknown function. & $\begin{array}{l}\text { SNP lies in a linkage region for autism } \\
\text { [57]. }\end{array}$ \\
\hline rs6791644 & 3 & 60746148 & Intron of $F H I T$ & $\begin{array}{l}\text { Encodes a diadenosine } 5^{\prime}, 5^{\prime \prime \prime}-\mathrm{P} 1, \mathrm{P} 3- \\
\text { triphosphate hydrolase involved in purine } \\
\text { metabolism. FHIT has a major role in } \\
\text { regulating beta-catenin-mediated gene } \\
\text { transcription. Expression in many tissues } \\
\text { including the brain. }\end{array}$ & $\begin{array}{l}\text { Gene is affected by CNVs in autism [ } 57 \text {, } \\
85] \text {. }\end{array}$ \\
\hline rs 10983238 & $9 \mathrm{q} 33.1$ & 118373504 & Intron of $A S T N 2$ & $\begin{array}{l}\text { Encodes astrotactin 2, a membrane protein } \\
\text { expressed in multiple tissues including the } \\
\text { brain. It is critically involved in neuron-glia } \\
\text { binding during the developmental periods of } \\
\text { glial-guided cell migration and assembly into } \\
\text { neuronal layers in the developing brain. A } \\
\text { homologue of the gene, ASTN, is involved in } \\
\text { neuronal migration. }\end{array}$ & $\begin{array}{l}\text { The gene was found disrupted by rare } \\
\text { CNVs in patients with autism [57]. }\end{array}$ \\
\hline rs1764178 & 9 & 1046959 & $\begin{array}{l}\text { Coding exon of } \\
\text { DMRT2 }\end{array}$ & $\begin{array}{l}\text { Encodes doublesex and mab-3 related } \\
\text { transcription factor 2, a potential regulator of } \\
\text { sex differentiation. Expressed in multiple } \\
\text { tissues, including the brain. }\end{array}$ & $\begin{array}{l}\text { Site is known for CNVs. Falls into/close } \\
\text { to a suggestive linkage region for } \\
\text { autism }[1,8] \text {. }\end{array}$ \\
\hline rs3893215 & $11 \mathrm{p} 15.1$ & 17721406 & $\begin{array}{l}\text { Intron of } \\
K C N C 1\end{array}$ & $\begin{array}{l}\text { Encodes potassium voltage-gated channel } \\
\text { Shaw-related subfamily member } 1 \text {, a protein } \\
\text { belonging to the delayed rectifier class of } \\
\text { channel proteins and an integral membrane } \\
\text { protein that mediates the voltage-dependent } \\
\text { potassium ion permeability of excitable } \\
\text { membranes. }\end{array}$ & $\begin{array}{l}\text { The SNP is close to/within regions of } \\
\text { (suggestive) linkage to autism from a } \\
\text { meta-analysis [93] and primary studies } \\
{[8,27] \text {. }}\end{array}$ \\
\hline rs874426 & 11 & 19526139 & Intron of $N A V 2$ & $\begin{array}{l}\text { Encodes neuron navigator } 2 \text {, an retinoic acid- } \\
\text { responsive gene that seems to play a role in } \\
\text { neuronal development. It is highly expressed } \\
\text { in the fetal and adult brain. }\end{array}$ & $\begin{array}{l}\text { The SNP is close to/within regions of } \\
\text { (suggestive) linkage to autism from a } \\
\text { meta-analysis [93] and primary studies } \\
{[8,27] \text {. }}\end{array}$ \\
\hline rs7995215 & $13 \mathrm{q} 31.3$ & 93206507 & Intron of $G P C 6$ & $\begin{array}{l}\text { Encodes glypican } 6 \text {. The glypicans comprise a } \\
\text { family of glycosylphosphatidylinositol- } \\
\text { anchored heparin sulfate proteoglycans. The } \\
\text { glypicans have been implicated in the control } \\
\text { of cell growth and division. Glypican } 6 \text { is a } \\
\text { putative cell surface coreceptor for growth } \\
\text { factors, extracellular matrix proteins, } \\
\text { proteases and anti-proteases. Expressed in } \\
\text { multiple tissues including the brain. }\end{array}$ & $\begin{array}{l}\text { CNVs in the gene have been noted in a } \\
\text { study on autism [57]. }\end{array}$ \\
\hline rs2360997 & 14 & 75882244 & $\begin{array}{l}\text { Within } 25 \mathrm{~kb} \\
\text { upstream of } \\
\text { ESRRB }\end{array}$ & $\begin{array}{l}\text { Encodes estrogen-related receptor beta, a } \\
\text { protein with similarity to the estrogen } \\
\text { receptor, expressed in brain and other tissues. }\end{array}$ & $\begin{array}{l}\text { CNVs in the gene have been noted in a } \\
\text { study on autism [57]. }\end{array}$ \\
\hline rs7164335 & $15 \mathrm{q} 23$ & 66502086 & ITGA11 & $\begin{array}{l}\text { Encodes integrin alpha } 11 \text {. Integrins are } \\
\text { heterodimeric integral membrame proteins } \\
\text { composed of an alpha chain and a beta chain. } \\
\text { The gene is expressed in multiple tissues } \\
\text { including the brain. }\end{array}$ & $\begin{array}{l}\text { The SNP lies close to linkage regions for } \\
\text { autism [8]. }\end{array}$ \\
\hline
\end{tabular}


Table 1 continued

\begin{tabular}{|c|c|c|c|c|c|}
\hline SNP & $\mathrm{Chr}$ & $\begin{array}{l}\text { Position } \\
\text { (bp) }\end{array}$ & Position & Gene function ${ }^{\mathrm{a}}$ & Previous findings for $\mathrm{ASD}^{\mathrm{a}}$ \\
\hline rs2677744 & $15 q 26.1$ & 89251445 & $\begin{array}{l}\text { Intron of } \\
\text { MAN2A2 }\end{array}$ & $\begin{array}{l}\text { Encodes mannosidase, alpha, class } 2 \mathrm{a} \text {, member } \\
2 \text {, expressed in the brain and many other } \\
\text { tissues. The protein is involved in N-glycan } \\
\text { synthesis. }\end{array}$ & $\begin{array}{l}\text { SNP lies close to linkage regions for } \\
\text { autism [8]. }\end{array}$ \\
\hline rs1471225 & 15 & 27675688 & $\begin{array}{l}\text { Within } 30 \mathrm{~kb} \\
\text { downstream } \\
\text { of KIAA0574 }\end{array}$ & $\begin{array}{l}\text { Encodes protein of unknown function } \\
\text { expressed in the brain and other tissues. }\end{array}$ & $\begin{array}{l}\text { The site is found in CNV regions in } 3 \\
\text { studies of autism }[22,57,85] .\end{array}$ \\
\hline rs7495052 & 15 & 90353033 & $\begin{array}{l}\text { Intron of } \\
\text { SLCO3A1 }\end{array}$ & $\begin{array}{l}\text { Encodes solute carrier organic anion transporter } \\
\text { family, member } 3 \mathrm{~A} 1 \text {, which might be } \\
\text { involved in the regulation of extracellular } \\
\text { vasopressin concentration in the human brain } \\
\text { and thus might influence the neuromodulation } \\
\text { of neurotransmission by cerebral } \\
\text { neuropeptides such as vasopressin. }\end{array}$ & $\begin{array}{l}\text { In/near suggestive linkage regions for } \\
\text { autism [8]. }\end{array}$ \\
\hline rs7187223 & 16 & 81015234 & $\begin{array}{l}\text { Intergenic, } \\
\text { within } 203 \mathrm{~kb} \\
\text { upstream from } \\
\text { CDH13 }\end{array}$ & $\begin{array}{l}\text { Encodes cadherin } 13 \text {, a member of the cadherin } \\
\text { superfamily. The encoded protein is a } \\
\text { calcium-dependent cell-cell adhesion } \\
\text { glycoprotein. This particular cadherin is a } \\
\text { putative mediator of cell-cell interaction in } \\
\text { the heart and may act as a negative regulator } \\
\text { of neural cell growth. }\end{array}$ & $\begin{array}{l}\text { The gene shows CNVs potentially } \\
\text { related to autism [22]. }\end{array}$ \\
\hline rs6565113 & 16 & 81665146 & $\begin{array}{r}\text { Intron of } \\
\mathrm{CDH} 13\end{array}$ & See above & See above \\
\hline rs4810685 & 20 & 45834120 & $\begin{array}{l}\text { Intron of } \\
\text { SULF2 }\end{array}$ & $\begin{array}{l}\text { Encodes heparin sulfatase 2. Heparan sulfate } \\
\text { proteoglycans (HSPGs) act as coreceptors for } \\
\text { numerous heparin-binding growth factors and } \\
\text { cytokines and are involved in cell signaling. } \\
\text { SULF2 can change properties of the } \\
\text { coreceptors by removing sulfate moieties. } \\
\text { The gene is essential for mammalian } \\
\text { development and survival, it shows } \\
\text { ubiquitous expression. }\end{array}$ & $\begin{array}{l}\text { The SNP lies close to a linkage region } \\
\text { for autism [1]. }\end{array}$ \\
\hline
\end{tabular}

${ }^{a}$ Where not indicated otherwise, the information is derived from the UCSC Browser, NCBI's OMIM, Gene and Unigene databases, and the Sullivan Lab Evidence Project website (location of SNP expanded by $\pm 5 \mathrm{Mb}$ for genome-wide linkage scans, $\pm 5 \mathrm{~kb}$ for GWAS, microarray and $\mathrm{CNV}$ studies, and $\pm 50 \mathrm{~kb}$ for signposts)

$A D H D$ attention-deficit/hyperactivity disorder, $A S D$ autism spectrum disorders, $C N V$ copy number variation, $S N P$ single nucleotide polymorphism

already indicated above, (rare) CNVs might also indicate genes pleiotropic for ASD and ADHD.

\section{Summary of shared heritability findings for ADHD and ASD}

Family based studies in clinical ADHD samples indicate that ASD symptoms are familial within ADHD families, and possibly related to similar familial origins as the ADHD symptoms. Twin studies suggest that 50-72\% of the phenotypic variance may be attributable to shared additive genetic factors. It appears that findings are robust for influences of gender, albeit inconsistent results are reported concerning this issue in family based studies on the one hand (more familial in males in one study and more familial in females in another study) and twin studies on the other hand (no effect of gender). In addition, age may have an effect with shared heritability estimates possibly increasing with older age. A few candidate gene studies have examined the association with candidate genes for one disorder in relationship to the other disorder. DAT1, DRD3, DRD4, COMT and MAOA (ADHD candidate genes) have been examined for their association with ASD. Findings for DRD4 were negative, for DAT1 and COMT inconclusive, and for $D R D 3$ and $M A O A$ at best cautiously positive. Serotonin related genes (ASD candidate genes) may be related to ADHD as well, yet no uniform picture emerges (reviewed elsewhere [87]). However, these candidate gene studies are largely underpowered, prohibiting firm conclusions regarding these findings. In some cases, rare mutations (such as copy number variations (CNVs), 
Table 2 Overview of single nucleotide polymorphisms (SNPs) among the published top-findings of GWAS in ASD which may also be involved in ADHD

\begin{tabular}{|c|c|c|c|c|c|}
\hline $\mathrm{SNP} / \mathrm{CNV}$ & $\mathrm{Chr}$ & Position (bp) & Position & Gene function ${ }^{\mathrm{a}}$ & Previous findings for $\mathrm{ADHD}^{\mathrm{a}}$ \\
\hline \multicolumn{6}{|c|}{ Wang et al. [96] } \\
\hline 6 SNPs & $5 \mathrm{p} 14.1$ & $\begin{array}{r}25934678- \\
26008578\end{array}$ & $\begin{array}{l}\text { Between } C D H 9 \text { and } \\
C D H 10\end{array}$ & $\begin{array}{l}\text { The genes encode type II classical cadherins } \\
\text { from the cadherin superfamily, integral } \\
\text { membrane proteins that mediate calcium- } \\
\text { dependent cell-cell adhesion. Both are } \\
\text { expressed in brain. }\end{array}$ & $\begin{array}{l}\text { The SNPs lie close to a linkage } \\
\text { region for ADHD [44]. }\end{array}$ \\
\hline $\begin{array}{l}\text { rs9395885, } \\
\text { rs9349688 }\end{array}$ & $6 \mathrm{p} 12.1$ & $\begin{array}{r}53853436- \\
53870051\end{array}$ & $\begin{array}{l}\text { Within intron of } \\
\text { LRRC1 }\end{array}$ & $\begin{array}{l}\text { Ecodes leucine-rich repeat-containing protein } 1 \text {, } \\
\text { a membrane protein of unknown function } \\
\text { found in epithelia (and brain). }\end{array}$ & $\begin{array}{l}\text { The SNPs are within a region } \\
\text { of suggestive linkage to } \\
\text { ADHD from a meta-analysis } \\
\text { [101]. }\end{array}$ \\
\hline rs9384952 & $6 \mathrm{p} 22.1$ & 116066757 & Intergenic & & $\begin{array}{l}\text { The SNPs are within a region } \\
\text { of suggestive linkage to } \\
\text { ADHD from a meta-analysis } \\
\text { [101]. }\end{array}$ \\
\hline 8 SNPs & $13 q 33.3$ & $\begin{array}{r}108823637- \\
108881899\end{array}$ & $\begin{array}{l}\text { Within } 200 \mathrm{~kb} \\
\text { downstream of } \\
\text { MYO16 }\end{array}$ & $\begin{array}{l}\text { Encodes myosin heavy chain Myr } 8 \text {, a gene } \\
\text { highly expressed in brain. This cytoskeletal } \\
\text { motor protein is involved in brain (especially } \\
\text { cerebellum) development. }\end{array}$ & $\begin{array}{l}\text { The SNPs lie close to } \\
\text { suggestive linkage result for } \\
\text { ADHD [9]. }\end{array}$ \\
\hline rs9932538 & $16 \mathrm{p} 12.3$ & 19116070 & $\begin{array}{l}\text { Within intron of } \\
\text { SYT17 }\end{array}$ & $\begin{array}{l}\text { The product of this gene, synaptotagmin XVII } \\
\text { (or B/K protein), is involved in vesicle } \\
\text { transport and is highly expressed in brain, } \\
\text { especially in the frontal and temporal lobes, the } \\
\text { hippocampus, the hypothalamus, the } \\
\text { amygdala, the substantia nigra, and the } \\
\text { pituitary [21] }\end{array}$ & $\begin{array}{l}\text { The SNP lies close to } \\
\text { significant linkage result for } \\
\text { ADHD [67]. }\end{array}$ \\
\hline \multicolumn{6}{|c|}{ Ma et al. $[54]^{\mathrm{b}}$} \\
\hline 5 SNPs & $5 \mathrm{p} 14$ & $\begin{array}{r}25934777- \\
25970827\end{array}$ & $\begin{array}{l}\text { Between } C D H 9 \text { and } \\
C D H 10\end{array}$ & $\begin{array}{l}\text { The genes encode type II classical cadherins } \\
\text { from the cadherin superfamily, integral } \\
\text { membrane proteins that mediate calcium- } \\
\text { dependent cell-cell adhesion. Both are } \\
\text { expressed in brain. See also above, same } \\
\text { findings reported by Wang et al. [96]. }\end{array}$ & $\begin{array}{l}\text { The SNPs lie close to a linkage } \\
\text { region for ADHD [44]. }\end{array}$ \\
\hline rs 2528795 & 7 & 73111430 & Within intron of $E L N$ & $\begin{array}{l}\text { This gene encodes the elastin isoform a } \\
\text { precursor. The mature protein that is one of the } \\
\text { two components of elastic fibers. The encoded } \\
\text { protein is rich in hydrophobic amino acids such } \\
\text { as glycine and proline, which form mobile } \\
\text { hydrophobic regions bounded by crosslinks } \\
\text { between lysine residues. Deletions and } \\
\text { mutations result in severe anomalies of the } \\
\text { aorta and skin, but the gene also falls into the } \\
\text { deletion found in Williams Beuren syndrome. } \\
\text { The latter is a contiguous gene syndrome with } \\
\text { neurobehavioral features and mental } \\
\text { retardation not easily accounted for by the } \\
\text { disruption of the elastin gene alone. }\end{array}$ & $\begin{array}{l}\text { The SNP lies within suggestive } \\
\text { linkage region for ADHD } \\
\text { from meta-analysis [101]. }\end{array}$ \\
\hline rs 171415 & 20 & 58229934 & $\begin{array}{l}\text { Within intron of } \\
\text { hypothetical genes } \\
\text { AX747739 and } \\
A K 309218\end{array}$ & Hypothetical gene(s) of unknown function. & $\begin{array}{l}\text { Less than } 10 \mathrm{~kb} \text { from one of } \\
\text { the top-findings of GWAS } \\
\text { for ADHD [63]. }\end{array}$ \\
\hline
\end{tabular}

$A D H D$ attention-deficit/hyperactivity disorder, $A S D$ autism spectrum disorders, $C N V$ copy number variation, $S N P$ single nucleotide polymorphism

a Where not indicated otherwise, the information is derived from the UCSC Browser, NCBI's OMIM, Gene and Unigene databases, and the Sullivan Lab Evidence Project website (location of SNP expanded by $\pm 5 \mathrm{Mb}$ for genome-wide linkage scans, $\pm 5 \mathrm{~kb}$ for GWAS, microarray and $\mathrm{CNV}$ studies, and $\pm 50 \mathrm{~kb}$ for signposts)

b Analysis was limited to SNPs showing $p$-values of $10^{-4}$ or smaller in the combined analysis of discovery and replication dataset 
premutations in the $5^{\prime}$ untranslated region of the FMRI gene on the X-chromosome, segmental duplications at breakpoints (BP4-BP5) of chromosome 15q13.2-q13.3, a deletion of $22 \mathrm{q} 11$ containing the COMT gene, and the rare XXYY syndrome) may account for some ADHD + ASD cases. However, given that these syndromes are mostly accompanied by characteristic physical abnormalities, they are unlikely to account for many ADHD + ASD cases without clear medical cause. With the exception of one study, only an indirect comparison of candidate linkage loci for ADHD and ASD can be made, since all loci are based on studies including patients with either ADHD or ASD. Limited evidence for overlap is found for overlapping suggestive linkage signals for ADHD and ASD. When applying looser criteria, 5p13, 9q33, and 16p13 appear to be the most fruitful loci to search for pleiotropic genes. With respect to GWAS findings, 16 SNPs related to ADHD may possibly involved in ASD and 25 SNPs related to ASD may also be of interest to ADHD. However, GWA studies are still in their very early beginning, so it may be somewhat premature to look for overlapping findings for ADHD and ASD.

\section{Recommendations for future genetic studies of ADHD + ASD}

GWAS have provided us with a tool to identify new genes for multifactorial disorders like ASD and ADHD. These studies require large samples to be investigated, with thousands of cases and equal numbers of controls to be analyzed. For this, international collaborations are being formed; one of the largest ones for psychiatric disorders being the Psychiatric GWAS Consortium [74]. One of the three main objectives of the Psychiatric GWAS Consortium is "cross-disorder analyses, including analyses of combinations of disorders and of phenotypes observed in two or more disorders ... based on recommendations of an expert committee. Because data are insufficient to determine what common cross-disorder etiological factors might exist, alternative phenotypes should be explored. GWAS analyses have produced surprising cross-disorder associations, such as those found for cancers and inflammatory bowel diseases, which could also exist for psychiatric disorders given the many common symptoms" (p. 548 [73]). No such cross-disorder analyses have been conducted for ADHD in combination with ASD. Therefore, we will propose several steps for future research that may facilitate the detection of pleiotropic etiological factors for ADHD and ASD.

A first step in future family genetic studies on the shared etiology of ADHD and ASD would be to assess ADHD and ASD in both parents and (multiple) off-spring. If parents and children are assessed using comparable phenotypic measures, a more direct examination can be made for intergenerational transmission of ADHD, ASD, and ADHD + ASD symptoms. It is of crucial importance to include not only categorical measures of ADHD and ASD into this design, but also to make use of quantitative phenotypic measures. The latter does more justice to the quantitative nature of both disorders; individuals with subthreshold symptoms are otherwise grouped together with individuals with no symptoms. Two types of families would be suitable for this approach: families in which the disorders are separately present in different family members, and families in which members are affected with both disorders, simultaneously. Both types of families may provide insight into pleiotropic genes and genes that are uniquely associated with one of both disorders: the former through simultaneously regressing gene effects on the ADHD and ASD phenotypes within families, the latter through regressing gene effects on the ADHD and ASD phenotypes within individuals.

A second (or parallel) step would be to assess candidate endophenotypes within a family-based design in which both ADHD and ASD are present in one or more family members. Endophenotypes, such as neuroimaging or neuropsychological functions, are defined as heritable vulnerability traits that form a link between genes and observable symptoms [39]. The first generation of ADHD and ASD GWAS studies using the ASD or ADHD clinical phenotypes made it clear that psychiatric diagnostic phenotypes may not be optimally suited for gene discovery. Compared to phenotypes, endophenotypes may improve statistical power by (a) being more heritable than phenotypes, (b) being more easily quantifiable than dichotomous DSM diagnostic categories, (c) being more reliable and objective than phenotypic measures, (d) being more biologically relevant, and (e) being more useful in creating genetically homogeneous subgroups of patients. Candidate endophenotypes for ADHD + ASD would most likely show the following characteristics: (a) more impaired in ADHD + ASD probands compared to ADHD or ASD probands, (b) more impaired in parents and siblings of ADHD + ASD-probands compared to those of ADHD or ASD probands, (c) stronger correlation between siblings in ADHD + ASD families compared to those in ADHD or ASD families, (d) cross-correlating with both ADHD and ASD in family members. In extensive review on candidate ADHD + ASD endophenotypes (Rommelse et al. submitted), we concluded that executive functioning, response variability, social cognition, motor coordination, language and intelligence are the most promising candidate neuropsychological endophenotypes. Candidate structural brain endophenotypic measurements include overall brain size, corpus callosum and cerebellum size, and structural 
integrity of the fronto-striatal circuitry. Too little data existed on functional brain imaging measures to propose candidate endophenotypes in this domain. Body parameters that may be useful for future studies are finger length ratio, height and weight and, possibly, fatty acid abnormalities. By incorporating these candidate endophenotypes into molecular genetic studies, both statistical power as well as insight into gene-behavior pathways may be gained.

However, the endophenotype approach is not without its shortcomings. For example, it is not well established that endophenotypes are indeed more reliable and objective than clinical phenotypes [11]. Furthermore, a putative endophenotype might not be less 'genetically complex' or more heritable than the phenotype itself [11], thereby not automatically resulting in an increased power to detect genetic effects. For example, though useful [78] and potentially more powerful than studies of clinical phenotypes, quite substantial sample sizes are still needed when endophenotypes at the level of neurocognitive performance are used for genetic studies [11]. However, structural and functional neuroimaging measures do appear to be able to reduce necessary sample sizes for molecular genetic analyses considerably [58, 62]. Therefore, despite possible shortcomings, we would nevertheless recommend incorporating candidate endophenotypic measures in familygenetic research for ADHD + ASD.

Another recommendation is to analyze multiple endophenotypes at the same time. This could be achieved by combining related traits into a single outcome using principal component analyses or factor analyses. Hereby common underlying constructs are extracted based on covariance between measures while the number of variables is reduced. Main advantages over the use of multiple correlated endophenotypes in univariate analyses are an increased reliability and decreased risk of false positive results. A potential disadvantage of this approach may be the loss of information by removing variance that is specific to each of the endophenotypes. Alternatively, multivariate multi-level models may be used. Multivariate multi-level models flesh out the relationships between numerous intermediate phenotypes [82]. Using this technique, multiple explanatory genetic variables can be simultaneously included in the model (multivariately) and regressed on variables measured at the endophenotype and phenotype level. As most cases of ADHD and ASD are probably caused by many genes of small individual effect, incorporating the relationships between multiple genes, endophenotypes and the clinical phenotypes in the model are even more important. The multivariate endophenotype approach has already proved useful in various other domains of endophenotypic research [13, 71, 97] and will most likely prove fruitful in the search for common etiological factors for ADHD + ASD.
Last but not least, the effect of environmental variables on endophenotypic and phenotypic functioning should not be overlooked. A candidate endophenotype can be associated with a diagnosis, be heritable and be reliably assessed, but nevertheless be under (strong) influence of environmental factors. Gene-environment interactions (mainly related to early/obstetric variables) on the phenotype are increasingly reported in ADHD and ASD literature $[12,60,68,90,91$; see also elsewhere in this issue $]$ and may also exist for endophenotypes. Therefore, gene-environment interactions are of vital importance to take into consideration when studying a common etiological basis for both disorders.

In sum, properly designed and powered candidate gene and linkage studies are missing for ADHD + ASD. Recent GWAS for clinical ADHD and ASD phenotypes have identified a number of viable pleiotropy candidates. GWAS currently seem to be the most appropriate approaches to learn about the role of common genetic variants in the combined disorders. We propose that future studies examining shared familial etiological factors for ADHD and ASD (a) use a family-based design in which the same measurements are obtained from all family members, (b) incorporate a coherent set of candidate endophenotypic measures that are most likely shared risk factors for ADHD and ASD, (c) apply multivariate multi-level models for statistical analysis, in order to examine the relationships between the various endophenotypes and phenotypes, and (d) incorporate environmental measures into the design.

Conflict of interest statement Rommelse, Franke, Geurts and Hartman have no conflict of interest to disclose. Buitelaar has been in the past 3 years a consultant to/member of advisory board of/and/or speaker for Janssen Cilag BV, Eli Lilly, Bristol-Myer Squibb, Organon/Shering Plough, UCB, Shire, Medice, Servier, and Servier.

Open Access This article is distributed under the terms of the Creative Commons Attribution Noncommercial License which permits any noncommercial use, distribution, and reproduction in any medium, provided the original author(s) and source are credited.

\section{References}

1. Allen-Brady K, Miller J, Matsunami N, Stevens J, Block H, Farley M, Krasny L, Pingree C, Lainhart J, Leppert M, McMahon WM, Coon H (2008) A high-density SNP genomewide linkage scan in a large autism extended pedigree. Mol Psychiatry, epub ahead of print

2. Aman MG, Farmer CA, Hollway J, Arnold LE (2008) Treatment of inattention, overactivity, and impulsiveness in autism spectrum disorders. Child Adolesc Psychiatr Clin N Am 17:713-738

3. American Psychiatric Association (2000) Diagnostic and statistical manual of mental disorders, 4th edn, Text Revision. American Psychiatric Association, Washington, DC 
4. Anckarsäter H, Stahlberg O, Larson T, Hakansson C, Jutblad SG, Niklasson L (2006) The impact of ADHD and autism spectrum disorders on temperament, character, and personality development. Am J Psychiatry 163:1239-1244

5. Anderson BM, Schnetz-Boutaud N, Bartlett J, Wright HH, Abramson RK, Cuccaro ML, Gilbert JR, Pericak-Vance MA, Haines JL (2008) Examination of association to autism of common genetic variationin genes related to dopamine. Autism Res 1:364-369

6. Angold A, Costello EJ, Erkanli A (1999) Comorbidity. J Child Psychol Psychiatry 40:57-87

7. Asherson P, the IMAGE Consortium (2004) Attention-deficit hyperactivity disorder in the post-genomic area. Eur Child Adolesc Psychiatry 13:50-70

8. Autism Genome Project Consortium, Autism genome project consortium P, Paterson AD, Zwaigenbaum L, Roberts W, Brian J, Liu XQ, Vincent JB, Skaug JL, Thompson AP, Senman L, Feuk L, Qian C, Bryson SE, Jones MB, Marshall CR, Scherer SW, Vieland VJ, Bartlett C, Mangin LV, Goedken R, Segre A, Pericak-Vance MA, Cuccaro ML, Gilbert JR, Wright HH, Abramson RK, Betancur C, Bourgeron T, Gillberg C, Leboyer M, Buxbaum JD, Davis KL, Hollander E, Silverman JM, Hallmayer J, Lotspeich L, Sutcliffe JS, Haines JL, Folstein SE, Piven J, Wassink TH, Sheffield V, Geschwind DH, Bucan M, Brown WT, Cantor RM, Constantino JN, Gilliam TC, Herbert M, Lajonchere C, Ledbetter DH, Lese-Martin C, Miller J, Nelson S, Samango-Sprouse CA, Spence S, State M, Tanzi RE, Coon H, Dawson G, Devlin B, Estes A, Flodman P, Klei L, McMahon WM, Minshew N, Munson J, Korvatska E, Rodier PM, Schellenberg GD, Smith M, Spence MA, Stodgell C, Tepper PG, Wijsman EM, Yu CE, Rogé B, Mantoulan C, Wittemeyer K, Poustka A, Felder B, Klauck SM, Schuster C, Poustka F, Bölte S, Feineis-Matthews S, Herbrecht E, Schmötzer G, Tsiantis J, Papanikolaou K, Maestrini E, Bacchelli E, Blasi F, Carone S, Toma C, Van Engeland $\mathrm{H}$, de Jonge M, Kemner C, Koop F, Langemeijer M, Hijmans C, Staal WG, Baird G, Bolton PF, Rutter ML, Weisblatt E, Green J, Aldred C, Wilkinson JA, Pickles A, Le Couteur A, Berney T, McConachie H, Bailey AJ, Francis K, Honeyman G, Hutchinson A, Parr JR, Wallace S, Monaco AP, Barnby G, Kobayashi K, Lamb JA, Sousa I, Sykes N, Cook EH, Guter SJ, Leventhal BL, Salt J, Lord C, Corsello C, Hus V, Weeks DE, Volkmar F, Tauber M, Fombonne E, Shih A, Meyer KJ (2007) Mapping autism risk loci using genetic linkage and chromosomal rearrangements. Nat Genet 39:319-328

9. Bakker SC, van der Meulen EM, Buitelaar JK, Sandkuijl LA, Pauls DL, Monsuur AJ (2003) A whole-genome scan in 164 Dutch sib pairs with attention-deficit/hyperactivity disorder: suggestive evidence for linkage on chromosomes $7 p$ and $15 q$. Am J Hum Genet 72:1251-1260

10. Banaschewski T, Neale BM, Rothenberger A, Roessner V (2007) Comorbidity of tic disorders and ADHD - conceptual and methodological considerations. Eur Child Adolesc Psychiatry 16(suppl 1):i5-i14

11. Bearden CE, Freimer NB (2006) Endophenotypes for psychiatric disorders: ready for primetime? Trends Genet 22:306-313

12. Becker K, El-Faddagh M, Schmidt MH, Esser G, Laucht M (2008) Interaction of dopamine transporter genotype with prenatal smoke exposure on ADHD symptoms. J Pediatr 152:263-269

13. Benyamin B, Sørensen TI, Schousboe K, Fenger M, Visscher PM, Kyvik KO (2007) Are there common genetic and environmental factors behind the endophenotypes associated with the metabolic syndrome? Diabetologia 50:1880-1888

14. Bethea TC, Sikich L (2007) Early pharmacological treatment of autism: a rationale for developmental treatment. Biol Psychiatry 61:521-537
15. Biederman J, Newcorn J, Sprich S (1991) Comorbidity of attention deficit hyperactivity disorder with conduct, depressive, anxiety, and other disorders. Am J Psychiatry 148:564-577

16. Brookes K, Xu X, Chen W, Zhou K, Neale B, Lowe N, Anney R, Franke B, Gill M, Ebstein R, Buitelaar J, Sham P, Campbell D, Knight J, Andreou P, Altink M, Arnold R, Boer F, Buschgens C, Butler L, Christiansen H, Feldman L, Fleischman K, Fliers E, Howe-Forbes R, Goldfarb A, Heise A, Gabriëls I, Korn-Lubetzki I, Johansson L, Marco R, Medad S, Minderaa R, Mulas F, Müller U, Mulligan A, Rabin K, Rommelse N, Sethna V, Sorohan J, Uebel H, Psychogiou L, Weeks A, Barrett R, Craig I, Banaschewski T, Sonuga-Barke E, Eisenberg J, Kuntsi J, Manor I, McGuffin P, Miranda A, Oades RD, Plomin R, Roeyers H, Rothenberger A, Sergeant J, Steinhausen HC, Taylor E, Thompson M, Faraone SV, Asherson P (2006) The analysis of 51 genes in DSM-IV combined type attention deficit hyperactivity disorder: association signals in DRD4, DAT1 and 16 other genes. Mol Psychiatry 11:934-953

17. Bucan M, Abrahams BS, Wang K, Glessner JT, Herman EI, Sonnenblick LI, Alvarez Retuerto AI, Imielinski M, Hadley D, Bradfield JP, Kim C, Gidaya NB, Lindquist I, Hutman T, Sigman M, Kustanovich V, Lajonchere CM, Singleton A, Kim J, Wassink TH, McMahon WM, Owley T, Sweeney JA, Coon H, Nurnberger JI, Li M, Cantor RM, Minshew NJ, Sutcliffe JS, Cook EH, Dawson G, Buxbaum JD, Grant SF, Schellenberg GD, Geschwind DH, Hakonarson H (2009) Genome-wide analyses of exonic copy number variants in a family-based study point to novel autism susceptibility genes. PLoS Genet 5:e1000536

18. Buitelaar JK (2005) ADHD: strategies to unravel its genetic architecture. J Neural Transm Suppl 69:1-17

19. Caron C, Rutter M (1991) Comorbidity in child psychopathology: concepts, issues and research strategies. J Child Psychol Psychiatry 32:1063-1080

20. Carpenter Rich E, Loo SK, Yang M, Dang J, Smalley SL (2009) Social functioning difficulties in ADHD: association with PDD risk. Clin Child Psychol Psychiatry 14:329-344

21. Chin H, Choi SH, Jang YS, Cho SM, Kim HS, Lee JH, Jeong SW, Kim IK, Kim GJ, Kwon OJ (2006) Protein kinase Adependent phosphorylation of $\mathrm{B} / \mathrm{K}$ protein. Exp Mol Med 38:144-152

22. Christian SL, Brune CW, Sudi J, Kumar RA, Liu S, Karamohamed S, Badner JA, Matsui S, Conroy J, McQuaid D, Gergel J, Hatchwell E, Gilliam TC, Gershon ES, Nowak NJ, Dobyns WB, Cook EH Jr (2008) Novel submicroscopic chromosomal abnormalities detected in autism spectrum disorder. Biol Psychiatry 63:1111-1117

23. Constantino JN, Hudziak JJ, Todd RD (2003) Deficits in reciprocal social behavior in male twins: evidence for a genetically independent domain of psychopathology. J Am Acad Child Adolesc Psychiatry 42:458-467

24. Craig IW (2007) The importance of stress and genetic variation in human aggression. BioEssays 29:227-236

25. Das M, Bhowmik AD, Sinha S, Chattopadhyay A, Chaudhuri K, Singh M, Mukhopadhyay K (2006) MAOA promoter polymorphism and attention deficit hyperactivity disorder (ADHD) in Indian children. Am J Med Genet B Neuropsychiatr Genet 141:637-642

26. Domschke K, Sheehan K, Lowe N, Kirley A, Mullins C, O'sullivan R, Freitag C, Becker T, Conroy J, Fitzgerald M, Gill M, Hawi Z (2005) Association analysis of the monoamine oxidase $\mathrm{A}$ and $\mathrm{B}$ genes with attention deficit hyperactivity disorder (ADHD) in an Irish sample: preferential transmission of the MAO-A $941 \mathrm{G}$ allele to affected children. Am J Med Genet B Neuropsychiatr Genet 134:110-114

27. Duvall JA, Lu A, Cantor RM, Todd RD, Constantino JN, Geschwindt DH (2007) A quantitative trait locus analysis of 
social responsiveness in multiplex autism families. Am J Psychiatry $164: 656-662$

28. Elia J, Gai X, Xie HM, Perin JC, Geiger E, Glessner JT, D'arcy M, Deberardinis R, Frackelton E, Kim C, Lantieri F, Muganga BM, Wang L, Takeda T, Rappaport EF, Grant SF, Berrettini W, Devoto M, Shaikh TH, Hakonarson H, White PS (2009) Rare structural variants found in attention-deficit hyperactivity disorder are preferentially associated with neurodevelopmental genes. Mol Psychiatry, epub ahead of print

29. Faraone SV, Perlis RH, Doyle AE, Smoller JW, Goralnick JJ, Holmgren MA, Sklar P (2005) Molecular genetics of attentiondeficit/hyperactivity disorder. Biol Psychiatry 57:1313-1323

30. Farzin F, Perry H, Hessl D, Loesch D, Cohen J, Bacalman S, Gane L, Tassone F, Hagerman P, Hagerman R (2006) Autism spectrum disorders and attention-deficit/hyperactivity disorder in boys with the fragile X permutation. J Dev Behav Pediatr 27:137-144

31. Franke B, Neale BM, Faraone SV (2009) Genome-wide association studies in ADHD. Hum Genet, epub ahead of print

32. Farzin F, Perry H, Hessl D, Loesch D, Cohen J, Bacalman S, Gane L, Tassone F, Hagerman P, Hagerman R (2001) Should the diagnosis of attention-deficit/hyperactivity disorder be considered in children with pervasive developmental disorder? J Atten Disord 4:203-211

33. Freitag CM (2007) The genetics of autistic disorders and its clinical relevance: a review of the literature. Mol Psychiatry $12: 2-22$

34. Gadow KD, Roohi J, DeVincent CJ, Hatchwell E (2008) Association of ADHD, tics, and anxiety with dopamine transporter (DAT1) genotype in autism spectrum disorders. J Child Psychol Psychiatry 49:1331-1338

35. Gadow KD, Roohi J, DeVincent CJ, Kirsch S, Hatchwell E (2009) Association of COMT (Val158Met) and BDNF (Val66Met) gene polymorphisms with anxiety, ADHD and tics in children with autism spectrum disorder. J Autism Dev Disord, epub ahead of print

36. Gillberg C, Gillberg IC, Rasmussen P, Kadesjö B, Söderström H, Råstam M, Johnson M, Rothenberger A, Niklasson L (2004) Co-existing disorders in ADHD-implications for diagnosis and intervention. Eur J Child Adolesc Psychiatry 13:80-92

37. Gizer IR, Ficks C, Waldman ID (2009) Candidate gene studies of ADHD: a meta-analytic review. Hum Genet, epub ahead of print

38. Glessner JT, Wang K, Cai G, Korvatska O, Kim CE, Wood S, Zhang H, Estes A, Brune CW, Bradfield JP, Imielinski M, Frackelton EC, Reichert J, Crawford EL, Munson J, Sleiman PM, Chiavacci R, Annaiah K, Thomas K, Hou C, Glaberson W, Flory J, Otieno F, Garris M, Soorya L, Klei L, Piven J, Meyer KJ, Anagnostou E, Sakurai T, Game RM, Rudd DS, Zurawiecki D, McDougle CJ, Davis LK, Miller J, Posey DJ, Michaels S, Kolevzon A, Silverman JM, Bernier R, Levy SE, Schultz RT, Dawson G, Owley T, McMahon WM, Wassink TH, Sweeney JA, Nurnberger JI, Coon H, Sutcliffe JS, Minshew NJ, Grant SF, Bucan M, Cook EH, Buxbaum JD, Devlin B, Schellenberg GD, Hakonarson H (2009) Autism genome-wide copy number variation reveals ubiquitin and neuronal genes. Nature 459:569-573

39. Gould TD, Gottesman II (2006) Psychiatric endophenotypes and the development of valid animal models. Genes Brain Behav 5:113-119

40. Grady DL, Harxhi A, Smith M, Flodman P, Spence MA, Swanson JM, Moyzis RK (2005) Sequence variants of the DRD4 gene in autism: further evidence that rare DRD4 7R haplotypes are ADHD specific. Am J Med Genet B Neuropsychiatr Genet 136B:33-35

41. Guan L, Wang B, Chen Y, Yang L, Li J, Qian Q, Wang Z, Faraone SV, Wang Y (2009) A high-density single-nucleotide polymorphism screen of 23 candidate genes in attention deficit hyperactivity disorder: suggesting multiple susceptibility genes among Chinese Han population. Mol Psychiatry 14:546-554

42. Handen BL, Johnson CR, Lubetsky M (2000) Efficacy of methylphenidate among children with autism and symptoms of attention-deficit hyperactivity disorder. J Aut Dev Disord 30:245-255

43. Hattori J, Ogino T, Abiru K, Nakano K, Oka M, Ohtsuka Y (2006) Are pervasive developmental disorders and attentiondeficit/hyperactivity disorder distinct disorders? Brain Dev 28:371-374

44. Hebebrand J, Dempfle A, Saar K, Thiele H, Herpertz-Dahlmann B, Linder M (2006) A genome-wide scan for attention-deficit/ hyperactivity disorder in 155 German sib-pairs. Mol Psychiatry 11:196-205

45. Heiser P, Friedel S, Dempfle A, Konrad K, Smidt J, Grabarkiewicz J (2004) Molecular genetic aspects of attention-deficit/hyperactivity disorder. Neurosci Biobehav Rev 28:625-641

46. Hofvander B, Delorme R, Chaste P, Nydén A, Wentz E, Ståhlberg O, Herbrecht E, Stopin A, Anckarsäter H, Gillberg C, Råstam M, Leboyer M (2009) Psychiatric and psychosocial problems in adults with normal-intelligence autism spectrum disorders. BMC Psychiatry 9:35

47. Holtman M, Bölte S, Pousta F (2007) Attention deficit hyperactivity disorder symptoms in pervasive developmental disorders: association with autistic behavior domains and coexisting psychopathology. Psychopathol 40:172-177

48. Huang CH, Santangelo SL (2008) Autism and serotonin transporter gene polymorphisms: a systematic review and metaanalysis. Am J Med Genet B Neuropsychiatr Genet 147B:903913

49. Jain M, Palacio LG, Castellanos FX, Palacio JD, Pineda D, Restrepo MI, Muñoz JF, Lopera F, Wallis D, Berg K, BaileyWilson JE, Arcos-Burgos M, Muenke M (2007) Attention-deficit/hyperactivity disorder and comorbid disruptive behavior disorders: evidence of pleiotropy and new susceptibility loci. Biol Psychiatry 61:1329-1339

50. de Krom M, Staal WG, Ophoff RA, Hendriks J, Buitelaar J, Franke B, de Jonge MV, Bolton P, Collier D, Curran S, van Engeland H, van Ree JM (2009) A common variant in DRD3 receptor is associated with autism spectrum disorder. Biol Psychiatry 65:625-630

51. Lee DO, Ousley OY (2006) Attention-deficit hyperactivity disorder symptoms in a clinic sample of children and adolescents with pervasive developmental disorders. J Child Adolesc Psychopharmacol 16:737-746

52. Li D, Sham PC, Owen MJ, He L (2006) Meta-analysis shows significant association between dopamine system genes and attention deficit hyperactivity disorder (ADHD). Hum Mol Genet 15:2276-2284

53. Liu J, Nyholt DR, Magnussen P, Parano E, Pavone P, Geschwind D, Lord C, Iversen P, Hoh J, Ott J, Gilliam TC (2001) A genomewide screen for autism susceptibility loci. Am J Hum Genet 69:327-340

54. Ma D, Salyakina D, Jaworski JM, Konidari I, Whitehead PL, Andersen AN, Hoffman JD, Slifer SH, Hedges DJ, Cukier HN, Griswold AJ, McCauley JL, Beecham GW, Wright HH, Abramson RK, Martin ER, Hussman JP, Gilbert JR, Cuccaro ML, Haines JL, Pericak-Vance MA (2009) A genome-wide association study of autism reveals a common novel risk locus at 5p14.1. Ann Hum Genet 73:263-273

55. Maher B (2008) Personal genomes: The case of the missing heritability. Nature 456:18-21

56. Manor I, Tyano S, Mel E, Eisenberg J, Bachner-Melman R, Kotler M, Ebstein RP (2002) Family-based and association studies of monoamine oxidase $\mathrm{A}$ and attention deficit 
hyperactivity disorder (ADHD): preferential transmission of the long promotor-region repeat and its association with impaired performance on a continuous performance test (TOVA). Mol Psychiatry 7:626-632

57. Marshall CR, Noor A, Vincent JB, Lionel AC, Feuk L, Skaug J, Shago M, Moessner R, Pinto D, Ren Y, Thiruvahindrapduram B, Fiebig A, Schreiber S, Friedman J, Ketelaars CE, Vos YJ, Ficicioglu C, Kirkpatrick S, Nicolson R, Sloman L, Summers A, Gibbons CA, Teebi A, Chitayat D, Weksberg R, Thompson A, Vardy C, Crosbie V, Luscombe S, Baatjes R, Zwaigenbaum L, Roberts W, Fernandez B, Autism genome project consortium P, Scherer SW (2008) Structural variation of chromosomes in autism spectrum disorder. Am J Hum Genet 82:477-488

58. Mier D, Kirsch P, Meyer-Lindenberg A (2009) Neural substrates of pleiotropic action of genetic variation in COMT: a metaanalysis. Mol Psychiatry, epub ahead of print

59. Miller DT, Shen Y, Weiss LA, Korn J, Anselm I, Bridgemohan C, Cox GF, Dickinson H, Gentile J, Harris DJ, Hegde V, Hundley R, Khwaja O, Kothare S, Luedke C, Nasir R, Poduri A, Prasad K, Raffalli P, Reinhard A, Smith SE, Sobeih MM, Soul JS, Stoler J, Takeoka M, Tan WH, Thakuria J, Wolff R, Yusupov R, Gusella JF, Daly MJ, Wu BL (2009) Microdeletion/ duplication at 15q13.2q13.3 among individuals with features of autism and other neuropsychiatric disorders. J Med Genet 46:242-248

60. Muhle R, Trentacoste SV, Rapin I (2004) The genetics of autism. Pediatrics 113:e472-e486

61. Mulligan A, Anney RJ, O’Regan M, Chen W, Butler L, Fitzgerald M, Buitelaar J, Steinhausen HC, Rothenberger A, Minderaa R, Nijmeijer J, Hoekstra PJ, Oades RD, Roeyers H, Buschgens C, Christiansen H, Franke B, Gabriels I, Hartman C, Kuntsi J, Marco R, Meidad S, Mueller U, Psychogiou L, Rommelse N, Thompson M, Uebel H, Banaschewski T, Ebstein R, Eisenberg J, Manor I, Miranda A, Mulas F, Sergeant J, Sonuga-Barke E, Asherson P, Faraone SV, Gill M (2009) Autism symptoms in attention-deficit/hyperactivity disorder: a familial trait which correlates with conduct, oppositional defiant, language and motor disorders. J Autism Dev Disord 39:197-209

62. Munafò MR, Durrant C, Lewis G, Flint J (2009) Gene X environment interactions at the serotonin transporter locus. Biol Psychiatry 65:211-219

63. Neale BM, Lasky-Su J, Anney R, Franke B, Zhou K, Maller JB (2008) Genome-wide association scan of attention deficit hyperactivity disorder. Am J Med Genet B Neuropsychiatr Genet 147B:1337-1344

64. Nijmeijer JS, Hoekstra PJ, Minderaa RB, Buitelaar JK, Altink ME, Buschgens CJ, Fliers EA, Rommelse NN, Sergeant JA, Hartman CA (2008) PDD symptoms in ADHD, an independent familial trait? J Abnorm Child Psychol 37:443-453

65. Niklasson L, Rasmussen P, Oskarsdóttir S, Gillberg C (2009) Autism, ADHD, mental retardation and behavior problems in 100 individuals with 22q11 deletion syndrome. Res Dev Disabil 30:763-773

66. Oades RD (2008) Dopamine-serotonin interactions in attentiondeficit hyperactivity disorder (ADHD). Prog Brain Res 172:543565

67. Ogdie MN, Macphie IL, Minassian SL, Yang M, Fisher SE, Francks C, Cantor RM, McCracken JT, McGough JJ, Nelson SF, Monaco AP, Smalley SL (2003) A genomewide scan for attention-deficit/hyperactivity disorder in an extended sample: suggestive linkage on 17p11. Am J Hum Genet 72:1268-1279

68. Pamplona FA, Pandolfo P, Savoldi R, Prediger RD, Takahashi RN (2009) Environmental enrichment improves cognitive deficits in spontaneously hypertensive rats (SHR): relevance for attention deficit/hyperactivity disorder (ADHD). Prog Neuropsychopharmacol Biol Psychiatry, epub ahead of print
69. Pickles A, Starr E, Kazak S, Bolton P, Papanikolaou K, Bailey A, Goodman R, Rutter M (2000) Variable expression of the autism broader phenotype: findings from extended pedigrees. $\mathrm{J}$ Child Psychol Psychiatry 41:491-502

70. Posey DJ, Wiegand RE, Wilkerson J, Maynard M, Stigler KA, McDougle CJ (2006) Open-label atomoxetine for attentiondeficit/hyperactivity disorder symptoms associated with highfunctioning pervasive developmental disorders. J Child Adolesc Psychopharmacol 16:599-610

71. Price GW, Michie PT, Johnston J, Innes-Brown H, Kent A, Clissa P, Jablensky AV (2006) A multivariate electrophysiological endophenotype, from a unitary cohort, shows greater research utility than any single feature in the Western Australian family study of schizophrenia. Biol Psychiatry 60:1-10

72. Prince $J$ (2008) Catecholamine dysfunction in attention-deficit/ hyperactivity disorder: an update. J Clin Psychopharmacol 28:S39-S45

73. Psychiatric GWAS Consortium Coordinating Committee (2009) Genomewide association studies: history, rationale, and prospects for psychiatric disorders. Am J Psychiatry 166:540-556

74. Psychiatric GWAS Consortium Steering Committee (2009) A framework for interpreting genome-wide association studies of psychiatric disorders. Mol Psychiatry 14:10-17

75. Reiersen AM, Constantino JN, Grimmer M, Martin NG, Todd RD (2008) Evidence for shared genetic influences on selfreported ADHD and autistic symptoms in young adult Australian twins. Twin Res Hum Genet 11:579-585

76. Retz W, Rösler M, Supprian T, Retz-Junginger P, Thome J (2003) Dopamine D3 receptor gene polymorphism and violent behavior: relation to impulsiveness and ADHD-related psychopathology. J Neural Transm 110:561-572

77. Romanos M, Freitag C, Jacob C, Craig DW, Dempfle A, Nguyen TT, Halperin R, Walitza S, Renner TJ, Seitz C, Romanos J, Palmason H, Reif A, Heine M, Windemuth-Kieselbach C, Vogler C, Sigmund J, Warnke A, Schäfer H, Meyer J, Stephan DA, Lesch KP (2008) Genome-wide linkage analysis of ADHD using high-density SNP arrays: novel loci at 5q13.1 and 14q12. Mol Psychiatry 13:522-530

78. Rommelse NN, Arias-Vásquez A, Altink ME, Buschgens CJ, Fliers E, Asherson P, Faraone SV, Buitelaar JK, Sergeant JA, Oosterlaan J, Franke B (2008) Neuropsychological endophenotype approach to genome-wide linkage analysis identifies susceptibility loci for ADHD on 2q21.1 and 13q12.11. Am J Hum Genet 83:99-105

79. Ronald A, Simonoff E, Kuntsi J, Asherson P, Plomin R (2008) Evidence for overlapping genetic influences on autistic and ADHD behaviours in a community twin sample. J Child Psychol Psychiatry 49:535-542

80. Roohi J, DeVincent CJ, Hatchwell E, Gadow KD (2009) Association of a monoamine oxidase-A gene promoter polymorphism with ADHD and anxiety in boys with autism spectrum disorder. J Autism Dev Disord 39:67-74

81. Rowlandson PH, Smith C (2009) An interagency service delivery model for autistic spectrum disorders and attention deficit hyperactivity disorder. Child Care Health Dev, epub ahead of print

82. Sabb FW, Burggren AC, Higier RG, Fox J, He J, Parker DS, Poldrack RA, Chu W, Cannon TD, Freimer NB, Bilder RM (2009) Challenges in phenotype definition in the whole-genome era: multivariate models of memory and intelligence. Neuroscience, epub ahead of print

83. Santosh PJ, Baird G, Pityaratstian N, Tavare E, Gringras P (2006) Impact of comorbid autism spectrum disorders on stimulant response in children with attention deficit hyperactivity disorder: a retrospective and prospective effectiveness study. Child Care Health Dev 32:575-583 
84. Schellenberg GD, Dawson G, Sung YJ, Estes A, Munson J, Rosenthal E, Rothstein J, Flodman P, Smith M, Coon H, Leong L, Yu CE, Stodgell C, Rodier PM, Spence MA, Minshew N, McMahon WM, Wijsman EM (2006) Evidence for multiple loci from a genome scan of autism kindreds. Mol Psychiatry 11:1049-1060

85. Sebat J, Lakshmi B, Malhotra D, Troge J, Lese-Martin C, Walsh T, Yamrom B, Yoon S, Krasnitz A, Kendall J, Leotta A, Pai D, Zhang R, Lee YH, Hicks J, Spence SJ, Lee AT, Puura K, Lehtimäki T, Ledbetter D, Gregersen PK, Bregman J, Sutcliffe JS, Jobanputra V, Chung W, Warburton D, King MC, Skuse D, Geschwind DH, Gilliam TC, Ye K, Wigler M (2007) Strong association of de novo copy number mutations with autism. Science 316:445-449

86. Simonoff E, Pickles A, Charman T, Chandler S, Loucas T, Baird G (2008) Psychiatric disorders in children with autism spectrum disorders: prevalence, comorbidity, and associated factors in a population-derived sample. J Am Acad Child Adolesc Psychiatry 47:921-929

87. Sinzig J, Lehmkuhl G (2007) What do we know about the serotonergic genetic heterogeneity in attention-deficit/hyperactivity and autistic disorders? Psychopathol 40:329-337

88. Sinzig J, Walter D, Doepfner M (2009) Attention deficit/ hyperactivity disorder in children and adolescents with autism spectrum disorder. Symptom or syndrome? J Atten Disord, epub ahead of print

89. Smalley SL, Kustanovich V, Minassian SL, Stone JL, Ogdie MN, McGough JJ, McCracken JT, MacPhie IL, Francks C, Fisher SE, Cantor RM, Monaco AP, Nelson SF (2002) Genetic linkage of attention-deficit/hyperactivity disorder on chromosome $16 \mathrm{p} 13$, in a region implicated in autism. Am J Hum Genet 71:959-963

90. Sonuga-Barke EJ, Oades RD, Psychogiou L, Chen W, Franke B, Buitelaar J (2009) Dopamine and serotonin transporter genotypes moderate sensitivity to maternal expressed emotion: the case of conduct and emotional problems in attention deficit/ hyperactivity disorder. J Child Psychol Psychiatry, epub ahead of print

91. Steyaert JG, De la Marche W (2008) What's new in autism? Eur J Pediatr 167:1091-1101

92. Tartaglia N, Davis S, Hench A, Nimishakavi S, Beauregard R, Reynolds A, Fenton L, Albrecht L, Ross J, Visootsak J, Hansen R, Hagerman R (2008) A new look at XXYY syndrome: medical and psychological features. Am J Med Genet A 146A:15091522

93. Trikalinos TA, Karvouni A, Zintzaras E, Ylisaukko-oja T, Peltonen L, Jarvela I, Ioannidis JP (2006) A heterogeneity-based genome search meta-analysis for autism spectrum disorders. Mol Psychiatry 11:29-36

94. Tripp G, Wickens JR (2009) Neurobiology of ADHD. Neuropharmacology, epub ahead of print
95. Troost PW, Steenhuis MP, Tuynman-Qua HG, Kalverdijk LJ, Buitelaar JK, Minderaa RB, Hoekstra PJ (2006) Atomoxetine for attention-deficit/hyperactivity disorder symptoms in children with pervasive developmental disorders: a pilot study. J Child Adolesc Psychopharmacol 16:611-619

96. Wang K, Zhang H, Ma D, Bucan M, Glessner JT, Abrahams BS, Salyakina D, Imielinski M, Bradfield JP, Sleiman PM, Kim CE, Hou C, Frackelton E, Chiavacci R, Takahashi N, Sakurai T, Rappaport E, Lajonchere CM, Munson J, Estes A, Korvatska O, Piven J, Sonnenblick LI, Alvarez Retuerto AI, Herman EI, Dong H, Hutman T, Sigman M, Ozonoff S, Klin A, Owley T, Sweeney JA, Brune CW, Cantor RM, Bernier R, Gilbert JR, Cuccaro ML, McMahon WM, Miller J, State MW, Wassink TH, Coon H, Levy SE, Schultz RT, Nurnberger JI, Haines JL, Sutcliffe JS, Cook EH, Minshew NJ, Buxbaum JD, Dawson G, Grant SF, Geschwind DH, Pericak-Vance MA, Schellenberg GD, Hakonarson H (2009) Common genetic variants on 5p14.1 associate with autism spectrum disorders. Nature 459:528-533

97. Warren DM, Dyer TD, Peterson CP, Mahaney MC, Blangero J, Almasy L (2005) A comparison of univariate, bivariate, and trivariate whole-genome linkage screens of genetically correlated electrophysiological endophenotypes. BMC Genet 6(Suppl 1):S117

98. Weiss LA, Shen Y, Korn JM, Arking DE, Miller DT, Fossdal R, Saemundsen E, Stefansson H, Ferreira MA, Green T, Platt OS, Ruderfer DM, Walsh CA, Altshuler D, Chakravarti A, Tanzi RE, Stefansson K, Santangelo SL, Gusella JF, Sklar P, Wu BL, Daly MJ, Consortium Autism (2008) Association between microdeletion and microduplication at $16 \mathrm{p} 11.2$ and autism. $\mathrm{N}$ Engl J Med 358:667-675

99. Yonan AL, Alarcón M, Cheng R, Magnusson PK, Spence SJ, Palmer AA, Grunn A, Juo SH, Terwilliger JD, Liu J, Cantor RM, Geschwind DH, Gilliam TC (2003) A genomewide screen of 345 families for autism-susceptibility loci. Am J Hum Genet 73:886-897

100. Yoshida Y, Uchiyama $\mathrm{T}$ (2004) The clinical necessity for assessing attention deficit/hyperactivity disorder (AD/HD) symptoms in children with high-functioning pervasive developmental disorder (PDD). Eur Child Adolesc Psychiatry 13:307-314

101. Zhou K, Dempfle A, Arcos-Burgos M, Bakker SC, Banaschewski T, Biederman J (2008) Meta-analysis of genome-wide linkage scans of attention deficit hyperactivity disorder. Am J Med Genet B Neuropsychiatr Genet 147B:1392-1398

102. van der Zwaag B, Franke L, Poot M, Hochstenbach R, Spierenburg HA, Vorstman JA, van Daalen E, de Jonge MV, Verbeek NE, Brilstra EH, van 't Slot R, Ophoff RA, van Es MA, Blauw HM, Veldink JH, Buizer-Voskamp JE, Beemer FA, van den Berg LH, Wijmenga C, van Amstel HK, van Engeland $\mathrm{H}$, Burbach JP, Staal WG (2009) Gene-network analysis identifies susceptibility genes related to glycobiology in autism. PLoS One 4:e5324 